\title{
SHOULD RENATURALISED AND RECULTIVATED LANDSCAPES APPEAR IN LANDSCAPE TYPOLOGY?
}

\author{
MągorZata Luc ${ }^{1}$, JACEK SZMAŃdA² \\ ${ }^{1}$ Institute of Geography and Spatial Management, Jagiellonian University in Krakow, Poland \\ ${ }^{2}$ Institute of Geography, Pedagogical University of Cracow, Poland
}

Manuscript received: April 14, 2014

Revised version: July 28, 2014

LuC M., SZMAŃDA J., 2014. Should renaturalised and recultivated landscapes appear in landscape typology? Quaestiones Geographicae 33(3), Bogucki Wydawnictwo Naukowe, Poznań, pp. 65-75, 10 figs. DOI 10.2478/quageo-2014-0030, ISSN 0137-477X.

ABSTRACT: Landscapes constantly change under the influence of natural and anthropogenic factors. They can be destructive as well as leading to regeneration of landscapes which have been imbalanced. When this process occurs in a natural or human-controlled manner with the use of natural elements of the environment, it is called renaturalisation, and the resulting landscape - renaturalised landscape. Where landscape restitution occurs under the purposeful, sustainable and rational human influence, we talk of the recultivation process and the resulting landscape is termed recultivated. Examples of both of these terms added to landscape classification have been described based on several quarries existing within the City of Krakow.

KEY WORDS: landscape classifications,landscape renaturalisation,landscape recultivation

Address of the corresponding author: Małgorzata Luc, Institute of Geography and Spatial Management, Jagiellonian University in Krakow, Gronostajowa 7, 30-387 Kraków, Poland; e-mail:mluc@gis.geo.uj.edu.pl

\section{Introduction}

The surrounding environment is the site of a clash between naturally occurring processes (natural environment) and anthropogenic factors (anthropogenic environment) and the landscape generated is a mean of the two. The landscape constantly evolves under the influence of these two groups of factors (Antrop 1998) increase in contribution of anthropogenic factors to the environment leads to gradual imbalance between the two groups. The result is disharmony of landscape and its degradation (Bogdanowski 1976) and, finally, devastation (Szczęsny 1982, Degórski 2005). However, the degradation processes may be halted and even regress, both due to natural factors (renaturalisation) and due to man's intentional actions (recultivation). In this case the landscape reinstates its balance between both groups of factors or the domination of anthropogenic elements is substituted for the preponderance of environmental factors.

From the point of view of geoecology anthropogenic influence on a landscape may be enriching, compensating or destructive in nature (Richling, Solon 1993). Borkowski (2008) distinguishes three basic families of landscapes, according to the direction of change in harmony and for the needs of spatial management: (1) progressive landscapes (modern); (2) constant; (3) regressive (preserved). Most landscape classifications according to the degree of anthropisation take into account a progressive process of landscape change in response to anthropisation which is 
usually destructive and leads to landscape devastation. However, increasingly frequently we observe regenerative processes within landscape encompassing restoring natural and cultural values (Chmielewski 2013). They are encouraged by the proposed policy of sustainable development (Luc 2014).

In this article we signal the need for the delineation of two distinct types of landscapes: renaturalised and recultivated. The goal we set ourselves was to define renaturalised and recultivated landscape as exemplified by chosen quarries within the area of the city of Kraków.

\section{Landscape classification in the context of evaluation of the degree of anthropisation in a geographical environment}

Current landscape ecology research treats landscape as a holistic image of the processes ongoing within it (Degórski 2005, Myga-Piątek 2012), following the classic views on systemic unity of the geographical environment by Humboldt (1845), Rosenkrantz (1850) and Hettner (1927). In the view of landscape architects landscape is a spatial form created in result of human actions aiming to adapt the natural environment to their needs (Bogdanowski 1976); therefore it is an image of man economy (Guterson 1956). Myga-Piątek (2001) states that the interdisciplinary meaning of landscape suggests a synthetic vision of landscape genesis not only in the environmental but also in the cultural context.

The condition of a landscape can be evaluated by thorough study of the relationships between natural and anthropogenic processes shaping the areas that surround us. These relationships can be analysed by evaluating the degree of influence by man on a landscape (Fig. 1), and various attempts at classifying landscape according to its development have been published in scientific papers from the fields of environmental protection, architecture and landscape ecology. Having analysed this literature we have adapted the four types of landscape according to Szczęsny (1982) and Degórski (2005): primary, natural, cultural and devastated.

\section{Primary landscapes}

Landscapes which are the result of purely environmental factors and not influenced by humans are described as primary landscapes (Isaczenko 1976, Bogdanowski 1976, Szczęsny 1982, Degórski 2005, Chmielewski 2013). A primary landscape is a landscape consisting exclusively of environmental elements which have not been anthropogenically transformed or the changes due to human activity have been subtle enough to avoid influencing the functioning of the landscape. In case of the occurrence of catastrophic natural processes this landscape may become degraded but, in order to preserve its natural character, regeneration is left to the forces of nature.

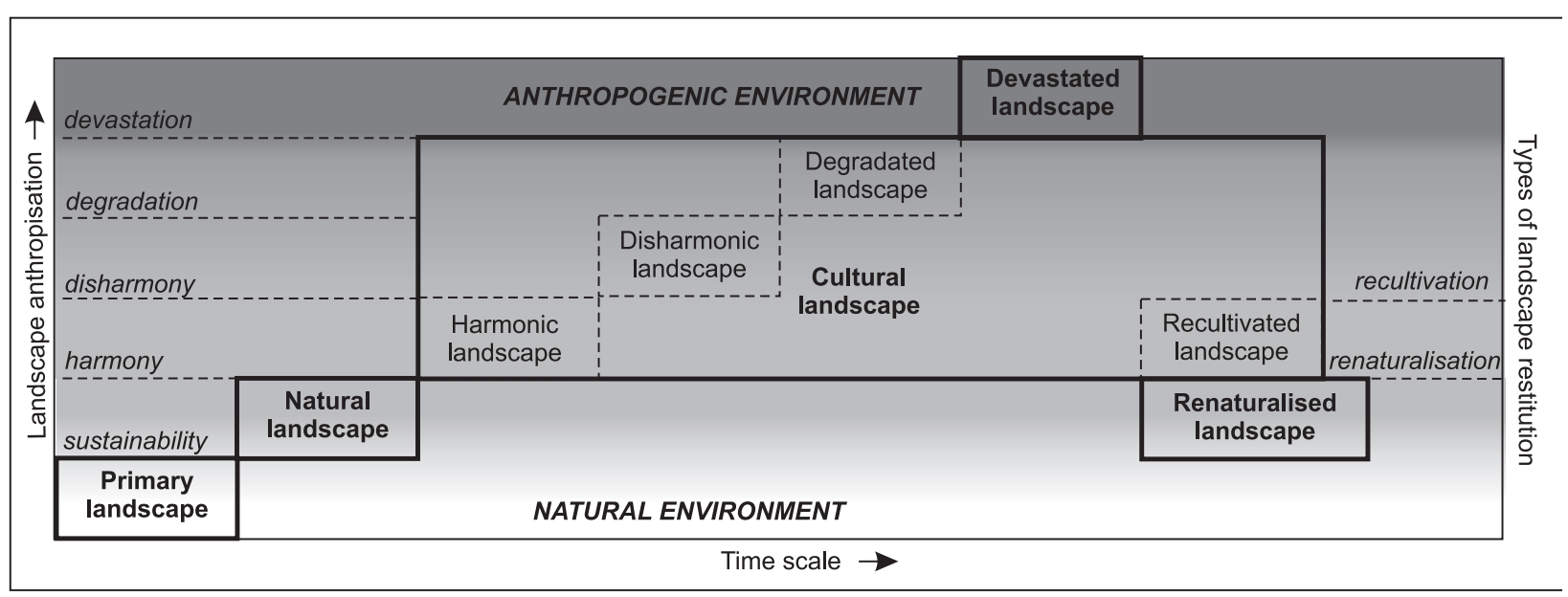

Fig. 1. Model of landscape typology in a context of the anthropisation degree 


\section{Natural landscapes}

Natural landscape, also defined by Szczęsny (1982) as an environmental landscape created by man with the use of elements of the environment, is shaped under the influence of the natural environment system and with minimal impact from the anthropogenic environment system (Degórski 2005). In a natural landscape the balance between environmental and anthropogenic environment is maintained and human activity is limited to rational utilisation of elements of the environment in synchrony with naturally occurring processes. If degradation of this landscape occurs due to natural catastrophic processes balance can be reinstated by means of natural processes as well as human intervention (Chmielewski 2013).

\section{Cultural landscapes}

Amongst the aforementioned four types of landscapes the most extensively differentiated one is the cultural landscape which is most concisely defined by Bogdanowski (1976) as a landscape permanently changed by man and sustained by constant human intervention. According to Degórski (2005) cultural landscape is shaped under the influence of processes occurring within the systems of both the natural as well as anthropogenic environment. The predominant influence of either of these systems decides on the degree of naturalisation or anthropisation of the landscape (Degórski 2005, Kistowski 2008).

Depending on the adaptation of anthropogenic components to its environmental elements, cultural landscape has been divided by Bogdanowski (1976) into: (1) harmonious, where components and processes which occur due to human intervention are well composed into the environmental elements; and (2) disharmonious (degenerated), characterised by the lack of mutual adaptation of environmental and anthropogenic elements. Myga-Piątek (2012) describes a specific type of cultural landscape - post-exploitational and specifically underlines landscapes which have lost their regenerative ability (anthropic landscapes - degraded within the group of anthropogenic landscapes). The author emphasises the immense recreational, economical, cultural, ecological and educational role of recultivation management undergoing in these areas. A very different approach is represented by Preobrażeński (1982) according to whom cultural landscapes always have a positive character - harmonious, rational, optimally utilised and managed. Their polar opposite is a group of acultural landscapes and the highest degree of anthropisation is achieved by degraded landscapes.

\section{Devastated landscapes}

Szczęsny (1982) coined the term devastated landscape to describe a type of landscape in which the equilibrium of anthropogenic and environmental factors, expressed by the imbalance of quality or quantity of one of its components, has been permanently disturbed. Devastated landscape is also described as a category by Degórski (2005) who defines it as the result of processes and phenomena occurring within the megasystem of a geographical environment under the influence of an anthropogenic environmental system, in result of which the functioning of an environment has been disturbed.

\section{Renaturalised and recultivated landscapes}

Discussions about the relationship between the natural and anthropogenic factors and processes shaping landscape often involve the issue of recultivation and renaturalisation of a landscape (Szczęsny 1982, Bogdanowski 1976, Solon 2008, Degórski 2005, Chmielewski 2013). Recently, Chmielewski (2013) described a subtype of landscape undergoing renaturalisation within environmental landscapes as well as a subtype of landscape undergoing regeneration within environmental and cultural and cultural landscape types. However, these subtypes relate to the landscapes being renaturalised and recultivated and not ones which are created in result of these processes.

The terms renaturalisation and recultivation are understood differently (Ciołek 1964, Isaczenko 1976, Bogdanowski et al. 1981, Szczęsny 1982, Ostęga, Uberman 2005). For this reason we have decided to formulate our own definitions of land- 
scape renaturalisation and recultivation. Landscape renaturalisation can therefore include the processes of reinstating environmental conditions in cultural and devastated landscapes by means of ecological succession as well as by purposeful, rational (according to Isaczenko 1976), sustainable and controlled introduction of environmental elements by man. Landscape recultivation is the reinstatement of harmony in disharmonious and degraded cultural landscape (according to theories by Kistowski 2008 and Chmielewski 2013) and/or in devastated landscape.

Why can a landscape with reinstated features of a natural landscape and harmonious cultural landscape not simply be named natural or harmonious cultural landscape, respectively? According to numerous researchers landscape constantly evolves (Antrop 1998, Naveh 2000, Borkowski 2008, Degórski 2005), additionally sustained human impact on environment has led to chronological succession of various types of landscape according to the increase in anthropisation (Bogdanowski 1976, Myga-Piątek 2012). Chronological layout taking into account increasing anthropopression associated with declining balance, according to various aforementioned researchers, can be systematised from primary landscape, through natural, harmonious cultural, disharmonious cultural, degraded cultural and devastated (Fig. 1). For the past decades processes leading to reinstatement of aesthetic and functional values to landscapes have been observed. They also include reinstating balance to landscapes. The result are landscapes which depict processes of renaturalisation and recultivation. These processes are helped by the policy of broadly understood sustainable development included, amongst others, in the Commission Communication of the Sustainable Development Strategy (CC 2005). However, natural and cultural values can not be fully reinstated to their original state, which is particularly well depicted in post-exploitation areas (quarries, opencast workings, dumps). The terrain structure of these areas, considered by geoecologists as the superior component of landscape which shapes the geosystem (Sołncew 1965, Kondracki 1976), undergoes major irreversible changes (Kostrowicki 1976). Therefore, in chronological terms, landscape resulting from renaturalisation and recul- tivation can not be reinstated to the same natural or harmonious cultural landscape from the past; instead it becomes one of two new landscape types: renaturalised or recultivated.

For these reasons we propose the following definitions: renaturalised landscape is a natural landscape which has undergone renaturalisation in result of ecological succession or anthropogenic influence; cultural recultivated landscape has the features of a cultural harmonious landscape formed in result of recultivation of a disharmonious, cultural degraded or devastated landscape (Fig. 1).

\section{A selection of recultivated and renaturalised landscapes within the City of Kraków}

Examples of renaturalised and recultivated landscapes within the City of Kraków are associated mainly with disused quarries and breaches in Jurassic limestone in the area of the Wawel hill and Krzemionki Podgórskie and isolated horsts in the Zakrzówek area (Fig. 2). Quarries are classified by different authors as cultural landscape (Nita, Myga-Piątek 2006), devastated landscape (Degórski 2005), or regenerated cultural landscape (Chmielewski 2013). We include chosen quarries which have undergone renaturalisation and recultivation in the appropriate categories proposed by us above.

\section{Renaturalised landscapes}

Renaturalised landscape was formed mostly by natural ecological succession of environmental elements into devastated quarries. The best known examples within Kraków are the quarries of Zakrzówek (Fig. 2): lake Zakrzówek (Fig. 3) and "Skałki Twardowskiego" quarry (Fig. 4). The beginnings of retrieval of Jurassic limestone in the Zakrzówek area, which was closed in 1990, reach back to the early Middle Ages (Sermet, Rolka 2013). The area of the current lake Zakrzówek, which has an area surface of 23 ha, began to fill with water after water pumps were disabled in 1992 (Sermet, Rolka 2013). It can therefore be considered, similarly to the neigh- 


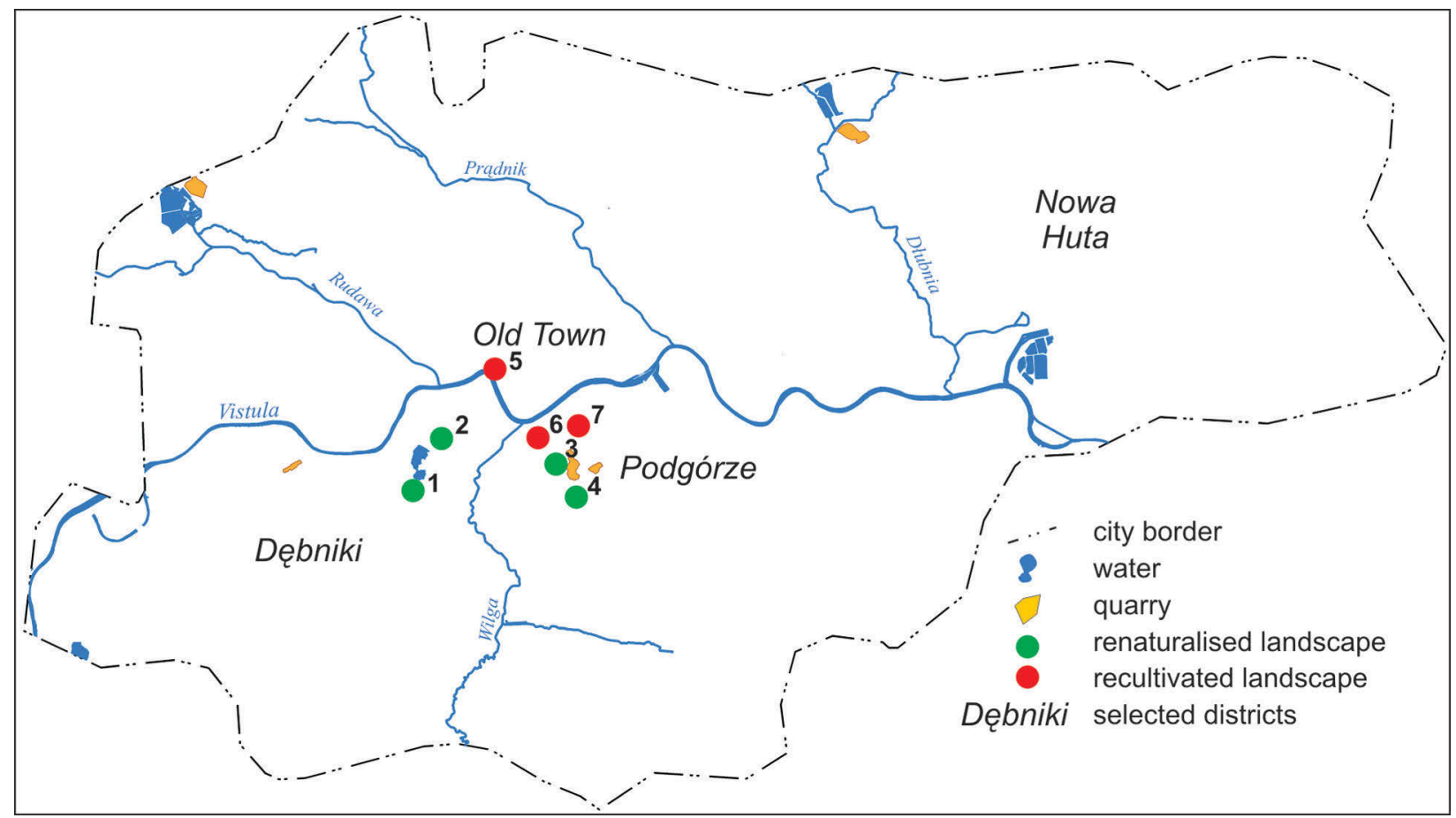

Fig. 2. Location of the selected renaturalised and recultivated landscapes in the City of Kraków:

1 - Zakrzówek Lake, 2 - “Skałki Twardowskiego" quarry, 3 - "Liban” quarry, 4 - “Bonarka” quarry, 5 - breach in the Wawel hill, 6 - Bednarski Park, 7 - "Pod Św. Benedyktem" quarry

bouring "Skałki Twardowskiego" quarry, a renaturalised area.

Another example of a renaturalised landscape formed under the influence of environmental processes within Kraków is the South aspect of the "Liban" quarry located in the area of Krzemionki Podgórskie, where limestone had been retrieved from the $14^{\text {th }}$ century up to 1986 (Ostęga, Uberman 2010). Within this damp and wooded section of the quarry (Fig. 5) signs of former devastation are not visible anymore as opposed to the North side of the site which is scarred not only by old industrial buildings but also by the withering remnants of a film set for Steven Spielberg's "Schindler's List" (Fig. 6). An example of a renaturalised landscape formed by means of environmental recultivation (Ostęga, Uberman 2010) is the "Bonarka" quarry (Fig. 7). The area, due to its exceptional geological features, became the Protected Geological Landscape park "Bonarka" in 1961.

\section{Recultivated cultural landscapes}

The most spectacular example of recultivated landscape within the area of Kraków is the breach on the side of the Wawel hill. It is documented that the South-West aspect of the hill, adjacent to the Dragon's Den, was a site of limestone mining (Górecki, Sermet 2010) from the early $19^{\text {th }}$ century. The exposed rock is well composed with the fortifications built on the top and harmonise with the overall terrain of the hill to such an extent, that it is difficult to identify signs of human intervention in the shape of the rock formation giving a backdrop to the statue of the Wawel Dragon (Fig. 8). Referring to the typological division of recultivation by Ostęga and Uberman (2010) it can be assumed that the site represents recultivation in the cultural direction.

Recultivation in the recreational direction may be exemplified by the recultivated landscapes of the quarries within Krzemionki Podgórskie horst, which occupy the North aspect of the Lasota hill: "Szkoła Twardowskiego" quarry (Fig. 9) and "Pod Św. Benedyktem" quarry (Fig. 10). The area of the "Szkoła Twardowskiego" quarry was turned into a recreational park in 1884-1896 at the initiative of a local teacher and councilman, Wojciech Bednarski, following the cessation of excavation of limestone and flint which had been ongoing from early Middle Ages to 1884. The park is considered the first example of post-industrial area recultivation (Górecki, Sermet 2010) 


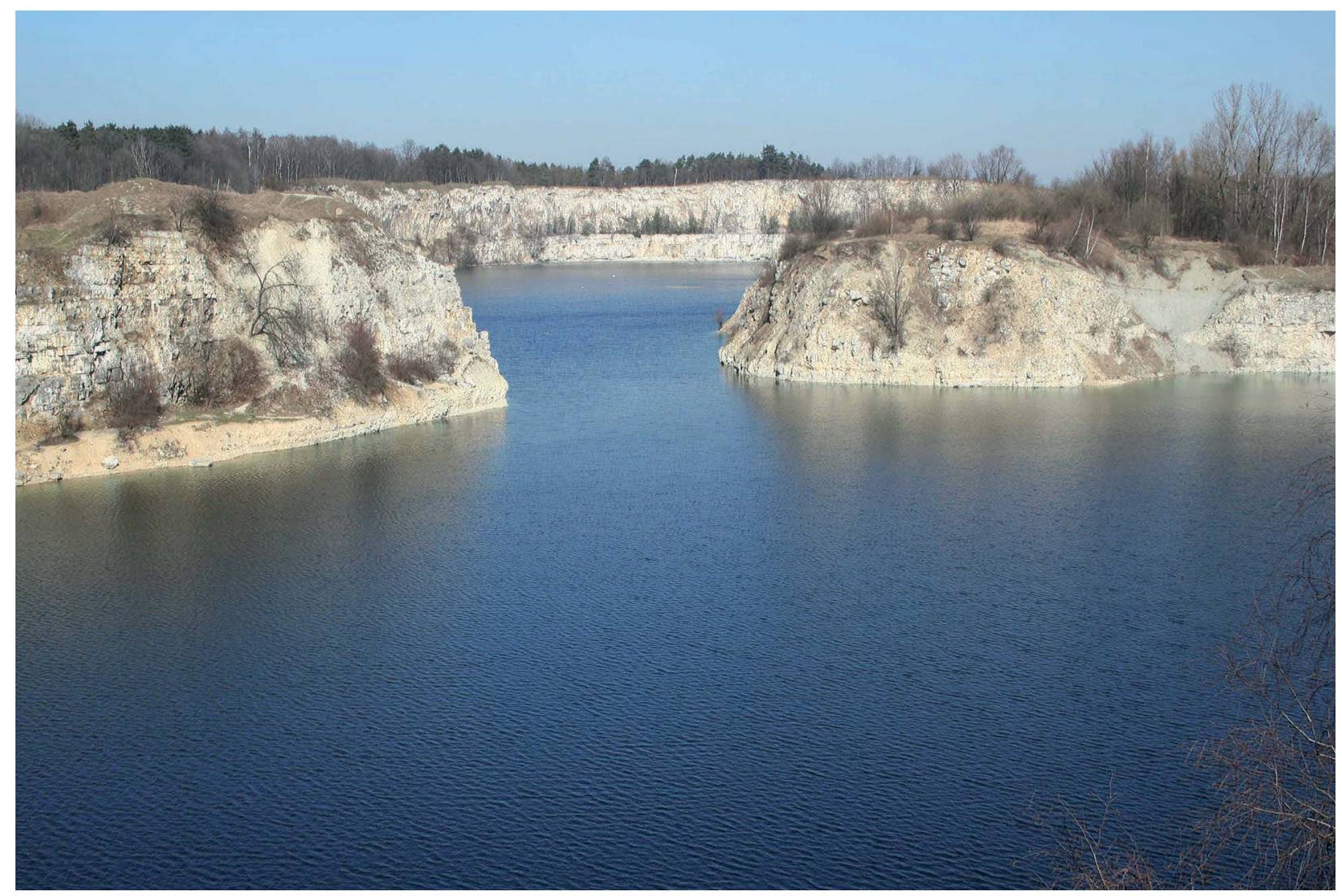

Fig. 3. Renaturalised landscape in the area of Zakrzówek Lake

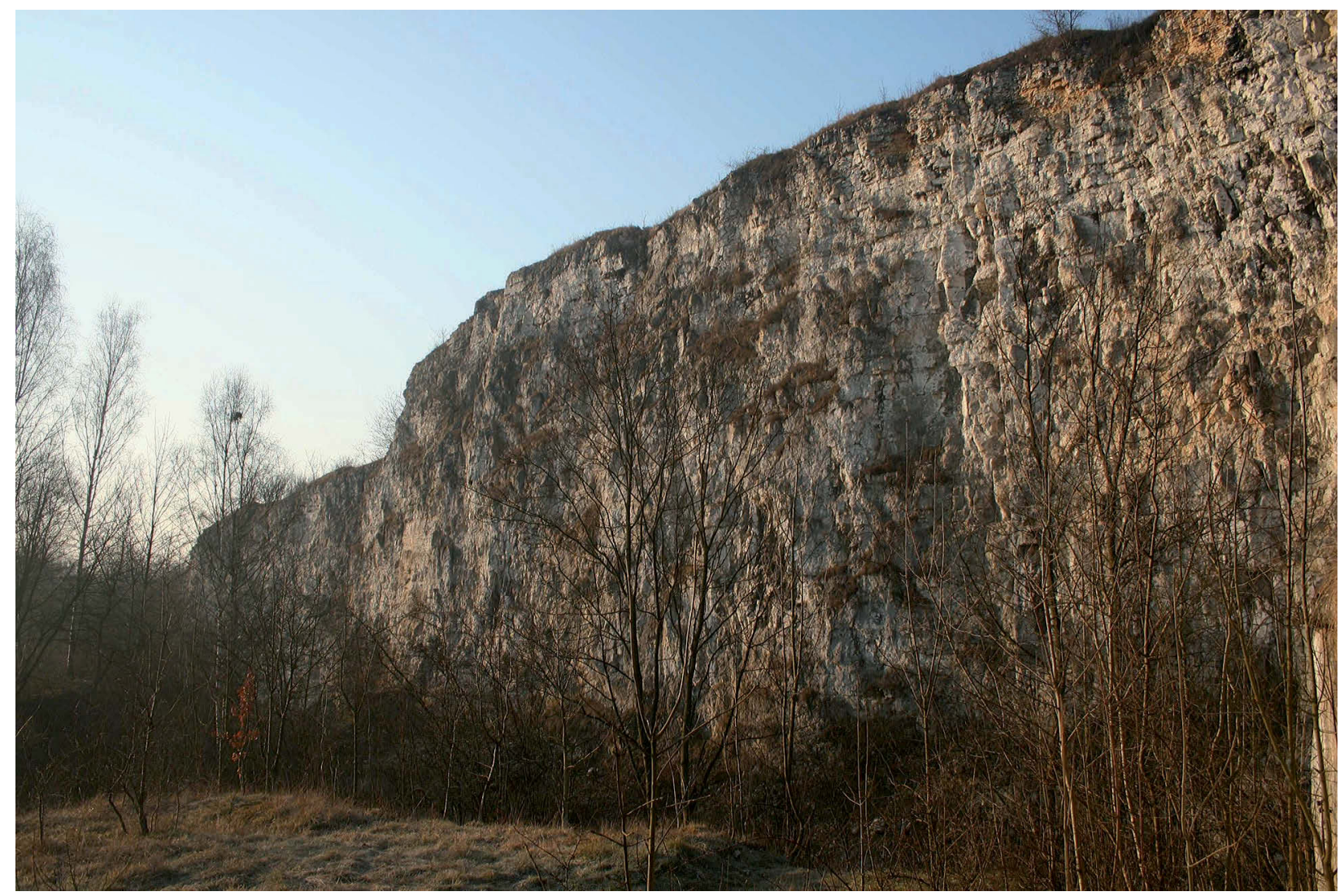

Fig. 4. Renaturalised landscape in the area of "Skałki Twardowskiego" quarry 


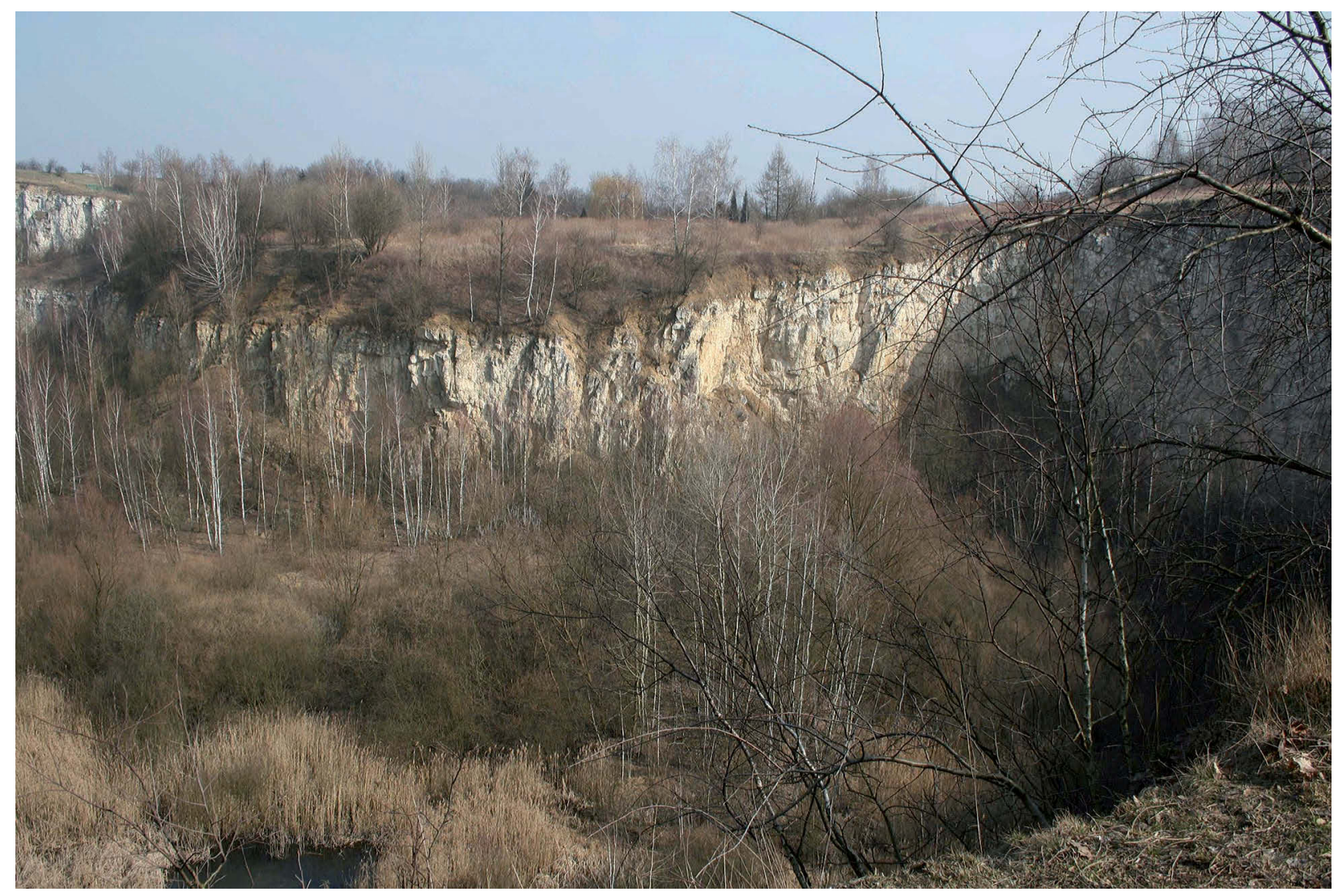

Fig. 5. Renaturalised landscape in the area in the South aspect of "Liban" quarry

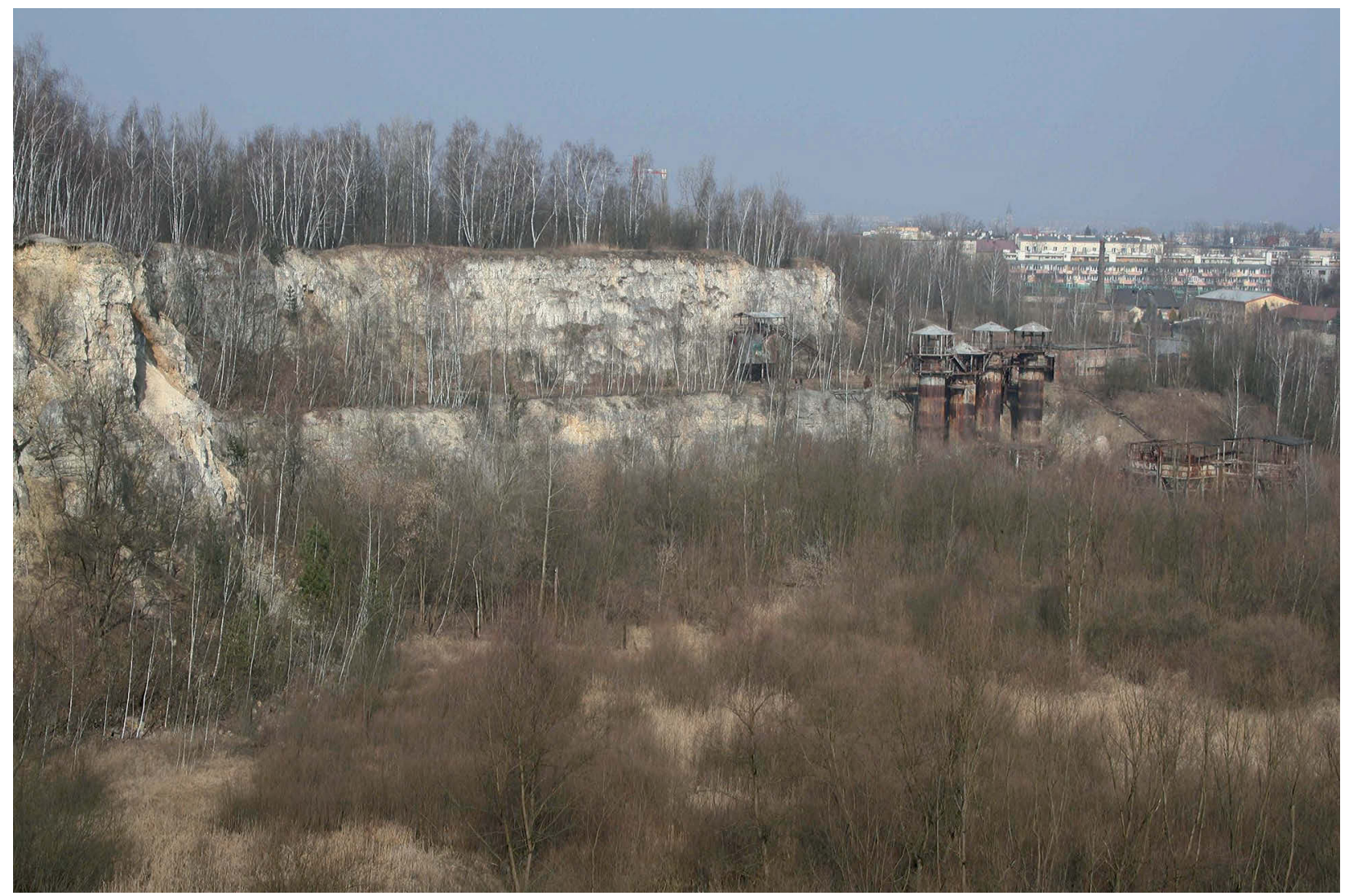

Fig. 6. Landscape in a renaturalisation process in the area in the North aspect of "Liban" quarry 


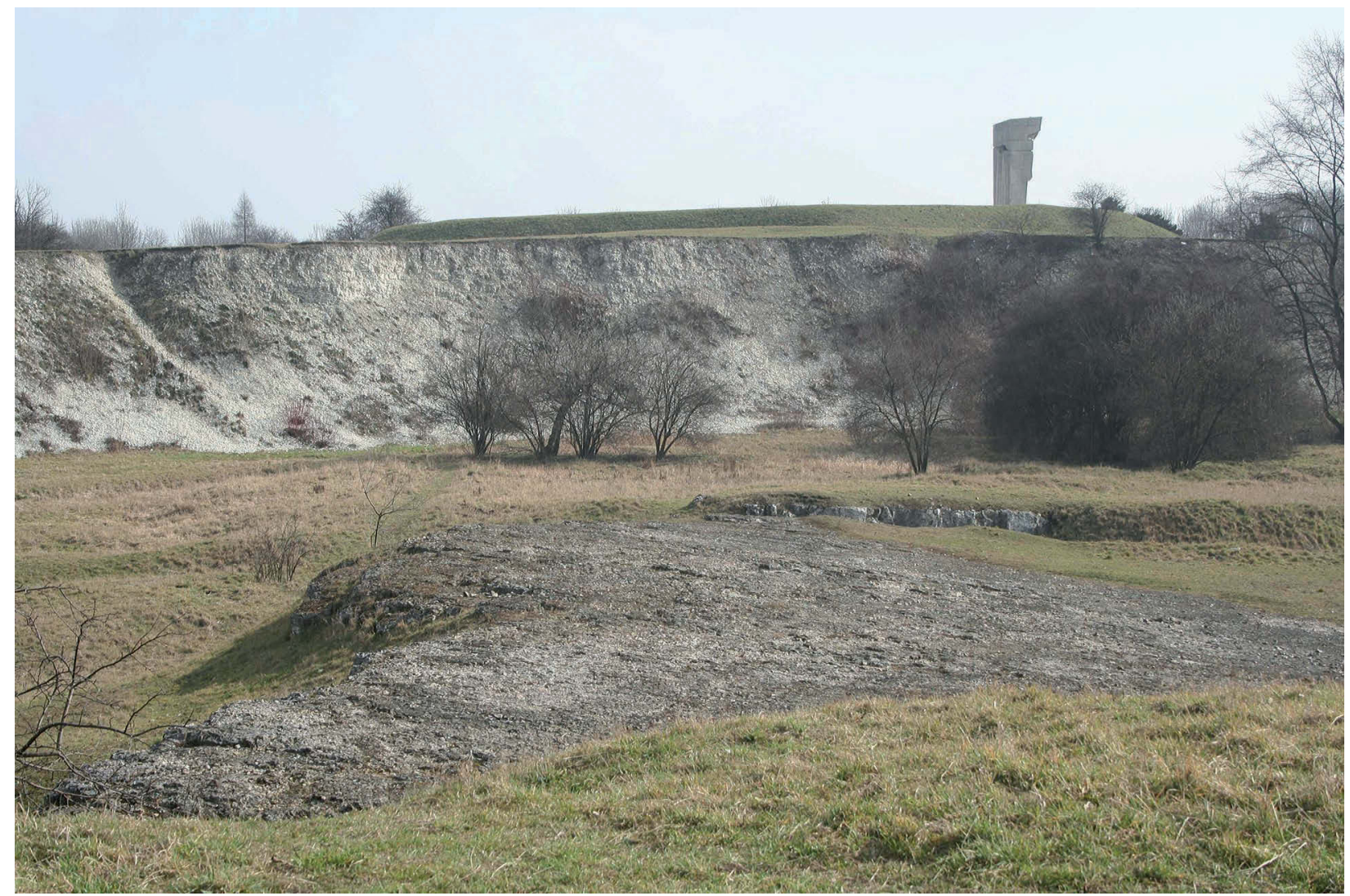

Fig. 7. Renaturalised landscape in the area of "Bonarka" quarry geological reserve

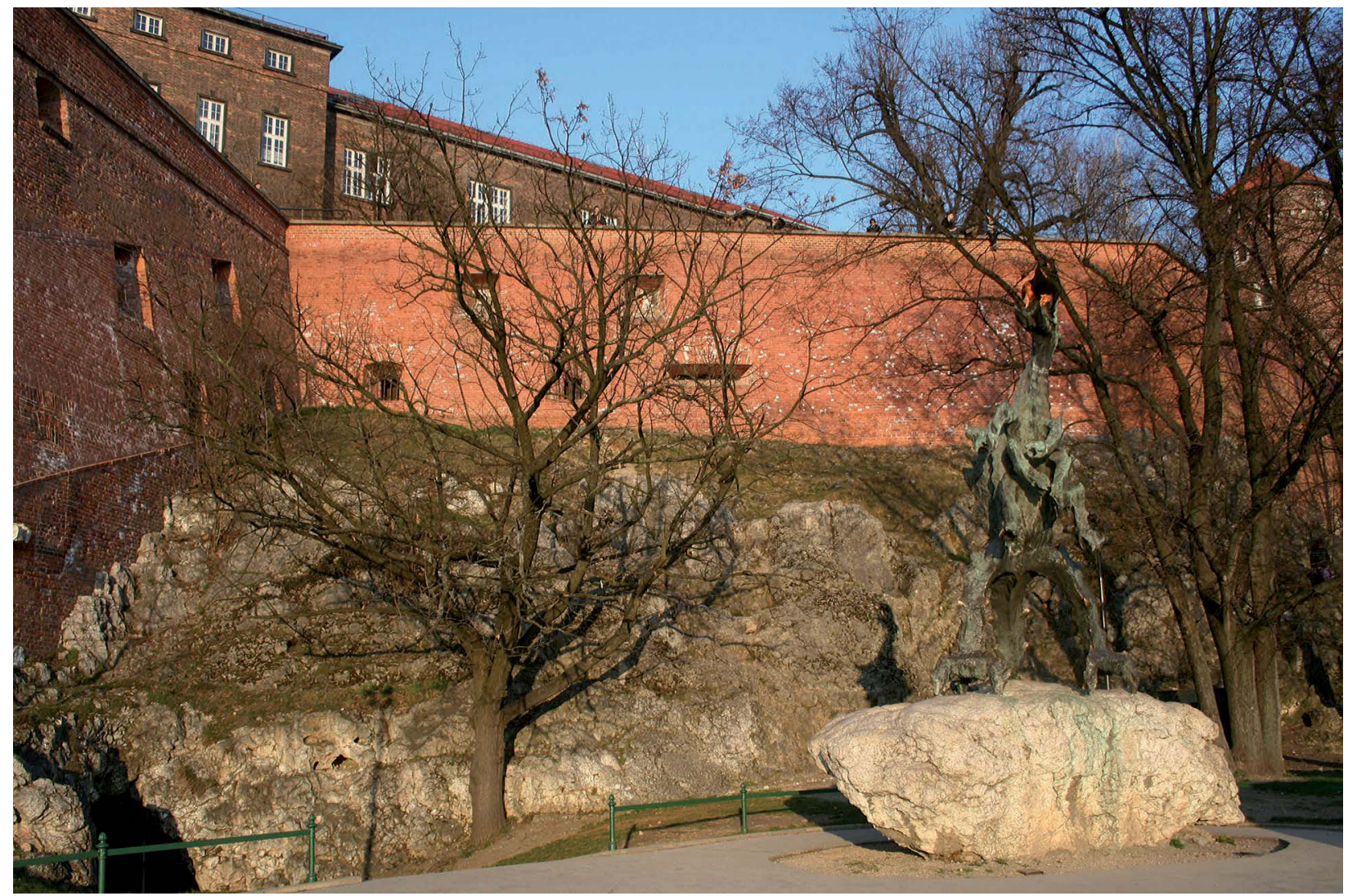

Fig. 8. Recultivated landscape - the Wawel hill breach and the Wawel Dragon 


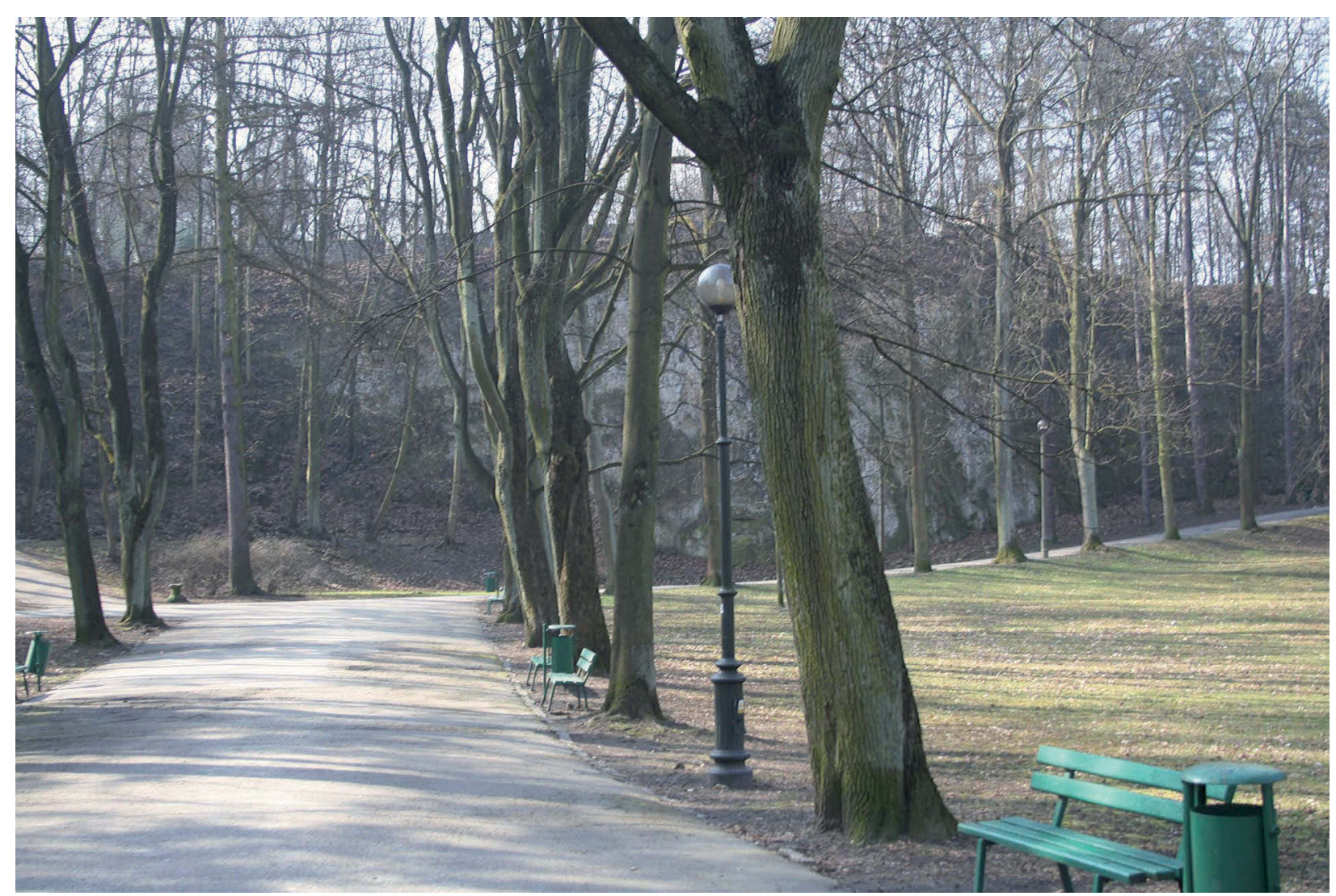

Fig. 9. Recultivated landscape in the area of "Szkoła Twardowskiego" quarry - Bednarski Park

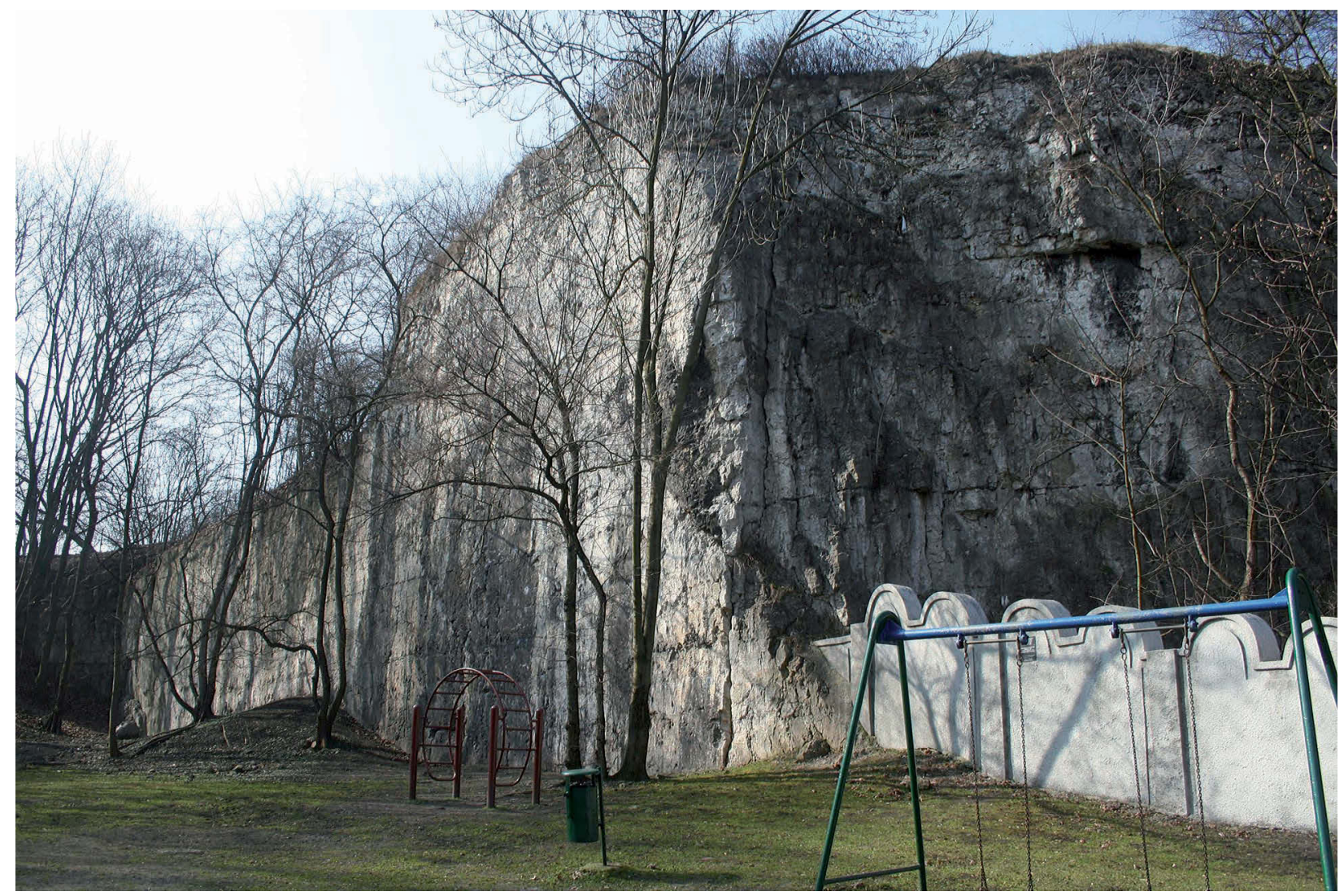

Fig. 10. Recultivated landscape in the area of "Pod Św. Benedyktem" quarry 
and has been named after its creator. Without doubt the limestone outcrops forming the border of this park are certainly an attractive element of the landscape. The "Pod Św. Benedyktem" quarry is the oldest of all quarries which functioned from the Middle Ages until the start of the $20^{\text {th }}$ century within Kraków (Górecki, Sermet 2010). The playground facilities and also one of the few preserved remains of the wall surrounding the Kraków Ghetto present on the site contribute to its modern appearance. The presence of the wall fragment may decide about describing this site as an example of the contemplation direction of recultivation (Ostęga, Uberman 2010).

\section{Conclusions}

Literature concerning landscape studies lacks in unequivocal, precise and thorough criteria for evaluation of landscape types which would take into account the degree of anthropisation. The indications for this have been published by Myga-Piątek (2012) and Chmielewski (2013). It has been commonly assumed that anthropisation has a negative meaning. However, many forms of human influence on environment (recultivation and revitalisation) leads to an improvement in its condition. Even if renaturalisation or recultivation resulted in formation of a cultural disharmonious, degraded or devastated landscape similar to the primary natural or cultural harmonious landscape, anthropogenic changes to terrain forms and hydrological relationships lead to enough permanent effects to call such landscapes renaturalised or recultivated.

Finally, it is worth indicating the issue of scale in landscape studies. Even if limited to the presented example of quarries, it is noticeable that regenerative processes affect them differently in various locations. In such situations a given area can be classified as several types of landscape or generalised and unequivocally classed as single specific type of landscape. Landscapes formed in result of interactions between environmental and anthropogenic elements, irrespective of the direction and character of changes, are difficult to classify due to their dynamic character and scale of observation. This classification is therefore subjective. Despite this we are of the opinion that due to the emphasis on the significance of restorative processes in geographical environment, outlining renaturalised and recultivated landscape types is logical.

\section{References}

Antrop M., 1998. Landscape change: Plan or chaos? Landscape and Urban Planning 41: 155-161.

Bogdanowski J., 1976. Kompozycja i planowanie w architekturze krajobrazu (Composition and planning in landscape architecture). Wyd. Ossolineum, Wrocław-Kraków.

Bogdanowski J., Łuczyńska-Bruzda M., Novák Z., 1981. Architektura krajobrazu (Landscape architecture). PWN, Warszawa-Kraków.

Borkowski Z., 2008. Harmonia wewnętrzna i zewnętrzna przedmiotów krajobrazu kulturowego jako kryterium jego typologii na potrzeby gospodarowania przestrzenią. (Internal and external harmony of the subjects of a cultural landscape as a criterion for its typology concerning the needs of spatial management). In: Zaręba A., Chylińska D. (eds), Studia krajobrazowe jako podstawa wtaściwego gospodarowania przestrzenia. Wrocławskie Towarzystwo Naukowe, Wrocław: 35-41.

CC, 2005. Commission Communication of 13 December 2005 on the review of the Sustainable Development Strategy - A platform for action [COM(2005) 658 final - not published in the Official Journal].

Chmielewski T.J., 2013. Systemy krajobrazowe: struktura, funkcjonowanie, planowanie (Landscape systems: structure, functioning, planning). Wydawnictwo Naukowe PWN, Warszawa.

Ciołek G., 1964. Zarys ochrony i ksztattowania krajobrazu (Outline of landscape protection and management). Arkady, Warszawa.

Degórski M., 2005. Krajobraz jako obiektywna wizualizacja zjawisk i procesów zachodzących $\mathrm{w}$ megasystemie środowiska geograficznego (Landscape as the objective visualization of phenomena and processes occurring in the megasystem of the geographical environment). Prace Komisji Krajobrazu Kulturowego PTG 4: 13-25.

Górecki J., Sermet E., 2010. Kamieniołomy Krakowa - dziedzictwo niedocenione (Quarries of Krakow - an underestimated heritage). In: Zagożdżona P.P., Madziarz M. (eds), Dzieje górnictwa - element europejskiego dziedzictwa kultury 3, Wrocław: 123-138.

Guterson H., 1956. Harmonie in der Landschaft. Solotłurn.

Hettner A., 1927. Geographie, ihre Geschichte, ihr Wesen und ihre Methoden. Breslau.

Humboldt A. von, 1845-1862. Kosmos. Entwurf einer physischen Weltbeschreibung 5 Bande. Stuttgart, Tübingen.

Isaczenko A.G., 1976. Prikładnoje landszaftowiedienije. Leningrad.

Kistowski M., 2008. Koncepcja równowagi krajobrazu - mity i rzeczywistość (The concept of landscape sustainability myths and reality). Problemy Ekologii Krajobrazu 21: 81-91.

Kondracki J., 1976. Podstawy regionalizacji fizycznogeograficznej (Basics of phisiogeographical regionalisation). PWN, Warszawa.

Kostrowicki A.S., 1976. A system-based approach to research concerning the geographical environment. Geographia Polonica 33(2): 27-38. 
Luc M., 2014. Placing the idea of sustainable landscape in ecophilosophy. Problemy Ekorozwoju - Problems Of Sustainable Development 9(1): 81-88.

Myga-Piątek U., 2001. Spór o pojecie krajobrazu w geografii i dziedzinach pokrewnych (Dispute over the concept of landscape in geography and related fields). Przeglad Geograficzny 73(1-2): 163-176.

Myga-Piątek U., 2012. Krajobrazy kulturowe. Aspekty ewolucyjne $i$ topologiczne (Cultural landscapes. Evolutionary and typological aspects). Uniwersytet Śląski, Katowice.

Naveh Z., 2000. What is holistic landscape ecology? A conceptual introduction. Landscape and Urban Planning 50: $7-25$.

Nita J., Myga-Piątek U., 2006. Krajobrazowe kierunki zagospodarowania terenów pogórniczych. (Landscape directions in management of post-mining areas). Przegląd Geologiczny 54(3): 256-262.

Ostęga A., Uberman R., 2005. Formalnoprawne problemy rewitalizacji terenów poprzemysłowych, w tym pogórniczych (Formal and legal problems of revitalisation in brownfield sites, including mining). Górnictwo i geoinżynieria 29(4): 115-127.

Ostęga A., Uberman R., 2010. Kierunki rekultywacji i zagospodarowania - sposób wyboru, klasyfikacja i przykłady
(Recultivation and management directions - the way of the selection, classification and examples). Górnictwo $i$ geoinżynieria 34(4): 445-461.

Preobrażenski W. (ed.), 1982. Ochrona tandszafów. Tołkowyj stawar. Progress, Moskwa.

Richling A., Solon J., 1993. Ekologia krajobrazu (Landscape ecology). PWN, Warszawa.

Rosenkranz J.K.F., 1850. System der Wissenschaft. Ein philosophisches Encheiridion. Köningsberg.

Sermet E., Rolka G., 2013. Pogórniczy spadek na zrębie Zakrzówka (The post-mining heritage at the Zakrzówek horst). In: Zagożdżona P.P., Madziarz M. (eds), Dzieje górnictwa - element europejskiego dziedzictwa kultury 5: 329-338.

Sołncew N.A., 1965. O wzajemnym stosunku przyrody "żywej" $i$ "martwej" (The mutual relation of nature "live" and "dead"). Przegląd Zagranicznej Literatury Geograficznej 2, IGiPZ PAN, Warszawa.

Solon J., 2008. Przegląd wybranych podejść do typologii krajobraz (The review of chosen approaches to landscape typology). Problemy Ekologii Krajobrazu 20: 25-33.

Szczęsny T., 1982. Ochrona przyrody i krajobrazu (Environmental and landscape protection). PWN, Warszawa. 